\title{
GERMAN INDUSTRIAL BONDS UNDER THE DAWES PLAN
}

One of the burdens assumed by Germany through its acceptance of the Dawes Plan is the requirement that 5,000,000,000 gold marks of bonds of German industrial concerns, secured by a public law mortgage on German industrial real property, be delivered to the reparation creditors on account of Germany's treaty obligations. The theory of imposing this burden on industry is based on the assumption that German industry is thereby committed to an obligation which is no greater than that which it carried before the war, and which it was able to discharge practically entirely by nominal payments in depreciated marks. ${ }^{1}$ In June, I923, the German Government had made a proposal to the Allied and Associated Governments of a mortgage on substantially all of Germany's real estate to secure an issue of $10,000,000,000$ gold marks of bonds. The Report of the First Committee of Experts, since known as the Dawes Plan, recognizing this proposal, found that the benefits to German industry through the depreciation of the currency so far outweighed the losses incurred through this depreciation that a burden of mortgage debt of the amount of 5 milliard gold marks on the industries of Germany, fairly apportioned, bearing a moderate rate of interest and payable on long maturity, would not create a burden greater than that which would have existed had there been no depreciation of currency. ${ }^{2}$

The Report of the First Committee of Experts, which was invited by the Reparation Commission on November 30, 1923, to "consider the means of balancing the budget and the measures to be taken to stabilize the currency" of Germany, provided three principal resources for payments to be made by Germany: (a) the current budget; (b) I I,000,000,000 gold marks of bonds se-

\footnotetext{
${ }^{2}$ Report of First Committee of Experts, Part I, IX, C. No consideration has been given in this statement to the effect of later German legislation requiring the payment of old unretired mark debts on a fifteen per cent. gold basis.

'Report of the First Committee of Experts, Part I, IX, C.
} 
cured on the railway system of the Reich, and the trancport tax; and (c) the 5,000,000,000 gold marks of industrial bonds referred to alore. To carry out and elaborate the general provisions of the Experts' Report with respect to the industrial obligations, an Organization Committee for Indurtrial Obligations was provided for. This Committee, consisting of a representative of the Ger:1an Government, a representative of German industry, two members appointed by the Reparation Commission and a fifth neutral nember, was given broad powers as to the details of the industrial bonds and the lien by which they were to be secured. Its report, carrying with it a draft of the proposed German legislation to carry out the plan, was presented to the London Conference of August, 1024. The report of the Committee and the Report of the First Comnittee of Experts was accepted by the Conference and were put into practical effect by the execution of the agreements between the German Government and the Allied and Associated Governments and the Reparation Commission approved at the Conference, and by the passage of the laws of the Reichstag contemplated by the Experts' Report.

\section{Provisions of the Bonds}

The Experts' Report provided for an issue of 5,000,000,000 gold marks of bonds, secured by a lien on the real estate of industrial concerns, bearing interest at the rate of five per cent. per annum and a sinking fund obligation of one per cent. per annum (in itself to determine the maturity of the bonds), the principal, interest and sinking fund to be guaranteed by the German Government. In view of the depletion of the liquid capital supply in Germany it was recommended that interest be waived entirely during the first year, that the interest for the second year be two and onehalf per cent., five per cent. for the third year, and that the maxi-

- The law relative to the charge on industry is the Gesetz über die Industriebelastung, passed August 30, 19a4. (Industrial Charges Iar.) 
mum payments of five per cent. annual interest and one per cent. annual sinking fund commence after the end of the third year. It was also provided that in the event of default in the payment of interest or sinking fund, recovery could be made from the German Government through the Commissioner of Controlled Revenues of the amounts in default." The Report also required that the bonds be delivered by the German Government to a Trustee to be appointed by the Reparation Commission, who would hold them, collecting the interest and sinking fund payments and paying the proceeds to the Agent for Reparation Payments, or dispose of them from time to time under the orders of the Reparation Commission.

The use of bonds as representative of the tax on industry was based, therefore, not only on the convenience of such obligations for specifying the deferred obligation of the debtors, but on the desirability of enabling the creditors to realize on reparation credits by selling the bonds on the international market. No details as to the character of the bonds, with a view of making them practically negotiable, was set out in the Experts' Report, and this burden fell on the Organization Committee. The Committee was faced with a conflict between the necessity for marketability of the bonds and its own conclusion that the great majority of individual industrial obligations which would have an international market was comprised within a limit of $1,500,000,000$ gold marks." Two alternatives were presented : first, that individual bearer obligations alone should be issued, and, second, that collateral trust obligations issued by some independent agency and secured by the individual industrial obligations should be utilized. The first alter-

'See below for discussion of this provision. The Experts' Report provides for an Agent for Reparation Payments, who shall act as the agency between the Reparation Commission and the various commissioners in charge of the Bank of Issue, the Commissioner of Railways, and the Commissioner of Controlled Revenues. In addition the Report provides for the appointment of a Trustee with the duty to receive and administer the railway and industrial bonds, and to be accountable to the Reparation Commission for those bonds.

- Report of the Organization Committee for Industrial Bonds to the Reparation Commission. 
native being undesirable because of the practical non-negotiability of the greater part of such individual obligations and the second being unavailable because of the terms of the Experts' Report, a compromise resulted. Two classes of bonds issued by the individual industrials were created: (a) negotiable bearer bonds, and (b) non-negotiable registered bonds. These latter non-negotiable bonds are used as collateral for a third class of bonds, which are, however, not issued by the industrial concerns but are issued by an independent agency, the Bank fur deutsche Industrie Obligationen (referred to below), and will be referred to as the Industrial Bonds of the Bank in order to distinguish them from the individual obligations issued by the industrial enterprises.

The respective amounts of the negotiable individual bonds and of the non-negotiable individual bonds were arrived at in the following manner. It was considered that the spirit of the Experts' Report required that the $1,500,000,000$ gold marks of bonds of individual industrials which were saleable be utilized to the greatest extent practicable; but, because the industrial concerns which would issue these $1,500,000,000$ gold marks of bonds were necessarily among the most important in Germany, it was decided that a considerable part of the bonds to be issued by them should be retained for use as security for the Industrial Bonds of the Bank. Accordingly it was provided that only one-lialf of the bonds of any concern liable to issue negotiable bonds should be sold and that the remaining one-half of the bonds of such concerns should fall into the non-negotiable class to be used as collateral for the Industrial Bonds of the Bank. This limited the negotiable individual obligations to one-half of $1,500,000,000$ gold marks, or 750,000,000 gold marks of bonds. It was then further provided that of these $750,000,000$ gold marks of bonds only $500,000,000$ gold marks could be negotiated by the Trustee. The final set-up of the $5,000,000,000$ gold marks total was, therefore, as follows: (a) $750,000,000$ gold marks of individual negotiable bearer bonds, of which the Trustee may choose 500,000,000 gold marks of bonds for sale, and (b) 4,250,000,000 gold marks of 
non-negotiable individual bonds, to be used as collateral for the Industrial Bonds of the Bank.

The utilization of the 4,250,000,000 gold marks of nonnegotiable individual obligations required, therefore, the creation of an intermediate agency. For this purpose the Industrial Charges Law provided for a German joint stock company created under German law and known as the "Bank fur deutsche Industrie-Obligationen," with a German Chairman of the Board and a board of directors composed of seven Allied appointees, seven German appointees, and the Chairman, with the principal function of issuing its Industrial Bonds.

The amount to which each industrial concern is to be liable having been established according to the system which is discussed below, each concern will deliver to the Bank and the Trustee its individual non-negotiable obligations, payable in gold marks and registered in the name of the Bank, for the total of the capital charge with which the concern is burdened. These bonds, in accordance with the Experts' Report, will not bear interest for the first year, will bear interest at the rate of two and one-half. per cent. for the second year, five per cent. for the third year, and five per cent. plus one per cent. sinking fund for the following years. A collective temporary bond, representing the joint obligation of the concerns subject to the Industrial Charges Law, was delivered to the Bank and the Trustee on November I, 1924, ${ }^{7}$ to be exchanged against the individual obligations not later than February 28, 1925. ${ }^{8}$

At the request of the Trustee the enterprises whose bonds are to be negotiable must deliver to the Bank negotiable bonds,

- The Bank actually issues 5,000,000,000 gold marks of its Industrial Bonds, retaining $750,000,000$ gold marks of these bonds to be issued to the Trustee if and when individual bearer bonds are returned by the Trustee to the Bank. In addition, the Bank may isstue not exceeding 200,000,000 gold marks of its Industrial Bonds against special collateral for the purpose of making adjustments with individual concerns on subsequent divisions of the charge (see below) or of taking the place of defaulted negotiable individual obligations (see below).

'Article by Dr. Alfred Cohen, of Hamburg, reprinted in Jourmal of Commerce, February 6, II, 17, 1925 .

- On the first distribution, the shipping concerns and private railways and tramways will issue collective non-negotiable obligations. 
payalble to bearer, in exchange for a like amount of non-negotiable obligations, for amounts determined by the Trustee and the Bank, but, of course, not exceeding $750,000,000$ gold marks in the aggregate. These negotiable obligations are subject to the control of and may be sold by the Trustee. The remaining 4,250,000,000 gold marks of non-negotiable individual obligations are held by the Bank, against which the Bank will issue a like amount of its Industrial Bonds, payable to bearer, and to be delivered to the Trustee. The Trustee may waive its right to sell any of the remaining 750,000,000 gold marks of negotiable individual bonds and may return them to the Bank to serve as cover for a like amount of Industrial Bonds of the Bank which will then be remitted to the Trustee. In any event as soon as 500,000,000 gold marks of individual negotiable obligations are sold by the Trustee, remaining $250,000,000$ gold marks of individual bearer obligations are to be returned by the Trustee to the Bank in exchange for a like principal amount of Industrial Bonds of the Bank.

The Industrial Bonds of the Bank, having been created for the purpose of enabling the Trustee to sell them, have been divided into two series in order to increase the low annual interest rate of two and one-half per cent. borne by the individual obligations in the second year and thus to hasten the period from which the Trustee will be able to negotiate the Industrial Bonds of the Bank. The first series is for 2,500,000,000 gold marks and will not bear interest during the first two years but will bear interest at the rate of five per cent. from the beginning of the third year. The second series is likewise for 2,500,000,000 gold marks, but will bear interest at the rate of five per cent. after the end of the first year. The Industrial Bonds of the Bank may be sold by the Trustee, with the consent of the Reparation Commission, or may likewise be used by the Trustee as collateral for new issues.

Interest and sinking fund payments on the individual obligations are nade to the Bank, and the debtor is released through this payment. In so far as the payments are in respect of negotiable individual bonds, they are turned over by the Bank for account of the Trustee. The sinking fund will operate to retire the individual obligations by lot under a plan to be determined by the 
Trustee and the Bank. The interest and sinking fund on the Industrial Bonds of the Bank are paid by the Bank to the account of the Trustee and the Bank is thereby discharged. The sinking fund on these latter bonds also operates by lot in a manner to be determined by the Bank and the Trustee. The sinking fund, both for the individual obligations and the Industrial Bonds of the Bank will be cumulative, that is, interest will be paid on the bonds retired through the sinking fund, and will retire the respective issues in about forty years. The bonds, both the individual obligations and the Industrial Bonds of the Bank may be redeemed at par as a whole commencing January 1,1937 . In addition, the individual negotiable obligations can, of course, be purchased by the debtors in the open market and canceled, and non-negotiable individual obligations can be retired through the purchase by the debtor of Industrial Obligations of the Bank and their delivery to the Bank in exchange for a like face amount of non-negotiable obligations.

With the consent of the German Government, bonds, payable in foreign currencies at rates so fixed that the total debt of $5,000,000,000$ gold marks and the $300,000,000$ gold marks of annual payments are not increased, may be issued in lieu of the Industrial Bonds of the Bank.

\section{Character of thf Security}

The real property of all industrial undertakings, including. navigation companies and private railways and tramways, but excluding agriculture and all concerns exclusively dedicated to banking, insurance, and the hotel industry, is subject to a public law mortgage (öffentliche Last), securing the interest and sinking fund of the individual obligations. In order to be effective against

- On the question of the transfer of funds in payment of interest and sinking fund on bonds beld outside Germany, the unsigned article in the Edirburgh Review of October, 1924, "The Dawes Plan and the London Conference" is of interest. See, for a discussion of the powers of the Transfer Committee constituted under the Experts' Report to supervise the transfer of funds out of Germany: Jean Parmentier, a member of the Transfer Committce, The Reparations Problem after London, Foreign Affairs, December 15, I9e4. 
third parties, this mortgage need not be recorded; but, upon application it may be placed on record. Undertakings of the Reich and of the states, and of concerns whose capital does not exceed 50,000 gold marks on the effective date of the Law are exempted from the charge. ${ }^{10}$ In addition the holders of the individual obligations enjoy a preference, junior only to the claims of employees and workmen against the unmortgaged assets in case of proceedings against the debtor concern. ${ }^{11}$

In the first instance the quota of debt to which each industrial concern will be subject will be calculated on the basis of the capital employed in the enterprise (Betriebsvermögen) as this capital was assessed for the capital tax (Vermögenssteuer) for the year $1924^{12}$ This uniformity of burden applies, however, only to certain groups of industries as the law provides that certain classes of enterprises must bear a given percentage of the total debt. In order to take care of the changes which may occur in the concerns during the life of the mortgage, and in order to avoid the accumulation of capital in enterprises which are created after the first distribution of the charge, the Industrial Charges Law provides that the charge will always lie on the ensemble of German industry. For this purpose it is provided that new divisions of the amounts for which each concern is liable will be made periodically. After five years from the effective date of the Law, this redistribution of the burden cannot take place more frequently than every two years. In the case of a concern where the Trustee and the Bank still hold a sufficient quantity of non-negotiable obligations, these readjustments will operate by a simple substitution

In addition, concerns whose profits go exclusively to the Government and the States are exempted. The German Government has the right to determine the extent to which the Communes and Communal Associations are subject to the charge. The 50,000 gold mark limit may be changed with the consent of the Bank and the Trustee.

A second law of August 30, 1924, (Aufbringungsgesetz) increases the classes of industries obliged to provide the annual charges. These additional concerns are not subject to any lien on their property. To the extent that the Bank receives payments from these additional concerns, it is authorized to waive the annual payments required by the Industrial Charges Law.

"Report of the Organization Committee.

${ }^{2}$ Except shipping concerns, private and narrow gauge railways and tramways, the capital of which, for technical reasons, is determined by estimate. 
of certificates. In case the Bank has insufficient obligations of a concern whose levy has been reduced, Industrial Bonds of the Bank may be delivered by the Bank as compensation. Enterprises which are founded between distributions and concerns whose property value has increased are required to contribute on the same basis as other concerns. These supplementary payments are made to the Bank and assigned to a reserve and guaranty fund.

The charge on real property is in the nature of a mortgage but it secures the interest and sinking fund payments only and does not constitute security for the payment of any capital sum, ${ }^{13}$ and, on foreclosure, the property passes subject to the lien. The charge is in the nature of a capital levy and ranks ahead of all existing obligations or liens on the property burdened except obligations under the Swiss-German Treaty of March $25,1923,{ }^{14}$ not exceeding 10,000,000 gold marks. ${ }^{15}$ The privilege against the unmortgaged assets does not constitute a lien.

In case of the default of an industrial concern on its interest or sinking fund commitments, the Bank, acting in agreement with the Trustee, can proceed immediately to execution upon the real and personal property of the defaulting concern. In case of default of an industrial concern which has outstanding non-negotiable obligations, the Bank and the Trustee will share in preference to the other creditors, with the exceptions above noted, to the extent of the interest and sinking fund obligations which have already matured and of interest and sinking fund obligations to mature up to the end of the year in which will take place the next redivision of the charge. This preference will, therefore, take care of the amounts which will be payable up to the time when the lien of the public law mortgage will be redivided on industry and new obligations of solvent concerns provided to take the place of the defaulted obligations.

\footnotetext{
"See "Law of Industrial Debentures Explained" in the Journal of Cornmerce, February 11 , 1925, for a discussion of the nature of the lien by Dr. Alfred Cohen, of Hamburg.

"Industrial Charges Law.

" Report of Organization Committee.
} 
Where, however, an industrial concern which has defaulted upon its interest or sinking fund commitments has issued negotiable obligations, of which part have been sold by the Trustee, the Trustee may accept from the Bank, in lieu of the defaulted individual obligations, Industrial Bonds of the Bank, ${ }^{16}$ or if it is believed that the lien on the real property is not sufficient-security for the payments to fall due in the future, the Trustee may intervene in the proceedings for the liquidation of the defaulting concern. For this purpose the Trustee will have a preference for the full extent of the obligations, past and future, in respect of which the default was made, not exceeding the principal amount of the negotiable obligations so defaulted. In such case the Trustee may require the sums to be collected from the assets of the defaulting concern and to be deposited in a bank to be chosen in agreement between the Trustee and the Reichsbank. The annual payments to the holders of the defaulted negotiable individual obligations will then be made by the Trustee. In case the Trustee takes Industrial Bonds of the Bank in lieu of the defaulted negotiable individual bonds, the Bank is subrogated to the rights of the holder of the individual obligations.

An additional important safeguard is provided for the immediate application of the guaranty of the German Government in case of default on the individual obligations. Under the Experts' Plan and the terms of the final protocol of the London Conference the gross revenues of the German Government from the customs and the taxes on tobacco, beer and sugar, and the net revenue of the spirits monopoly and any further tax which may be hereafter assigned thereto by the German Government are to be paid to the Commissioner for Controlled Revenues as security for the minimum payments from the budget required by the Plan. Under Annex No. 5 of the Experts' Plan, and under the Industrial Charges Law, in case of default on the interest or sinking fund on the individual obligations, the obligations representing this interest and sinking fund can be presented by the Trustee to the

\footnotetext{
* For this purpose, only Industrial Bonds of the Bank purchased out of its own resources or issued against special cover may be utilized.
} 
Commissioner of Controlled Revenues who shall purchase them at their face value out of the funds in his control destined to be paid over to the German Government. ${ }^{17}$ This provision does not apply, by the terms of the Industrial Charges Law, to the Industrial Bonds of the Bank, but the holders of these Industrial Bonds have a right of priority against other creditors of the Bank in respect of the individual obligations held by the Bank and of all rights and guaranties in respect of these individual obligations. The German Government may collect from the defaulting debtor in respect of any payments so made out of the Controlled Revenues.

Spectal Rigits of the Individual Debtors.

Considerable liberality is allowed to the debtors to liberate thenuselves in whole or in part from the charge.

As long as any of the obligations of a concern, whether negotiable or non-negotiable, remain under the control of the Bank and the Trustee, they may be repurchased by the debtor by payment at face value in foreign currency or bills, by payment in gold, or by delivery of Industrial Bonds of the Bank at face value. Since, however, the Industrial Bonds of the Bank must always be covered by a like principal amount of individual obligations, the obligations constituting such cover cannot be purchased by payment in currency, bills or gold unless there remains a sufficient quantity of Industrial Bonds of the Bank which have not been sold to the public which may be destroyed upon the cancellation of the individual obligations repurchased. Upon the repurchase of all the individual obligations issued by a concern it is freed of the lien upon its property and is discharged from its interest

"At the London Conference by agreement between the Allied and Associated Governments it was provided that the initial loan under the Experts" Plan of $800,000,000$ gold marks, should be entitled to "absolute priority as regards any resources of Germany so far as such resources may have been subjected to a general charge in favor of the said loan, and also as regards any resources that may arise as a result of the imposition of sanctions." The loan constitutes, among other things, a first charge on all payments provided for under the Experts' Report to or for the account of the Agent-General for Reparation Payments and a first charge by way of collateral security on the Controlled Revenues. 
and sinking fund commitments. In order to prevent the flow of capital into enterprises which have so paid off or repurchased all of their obligations outstanding and thus have freed their property from lien, and at the same time to encourage enterprises to repurchase their obligations, the Industrial Charges Law provides that, if after the repurchase of all the obligations of a concern outstanding, the capital employed in the business of the enterprise increases more than fifteen per cent., the excess over fifteen per cent. will be subject to the charge of future distributions. This further charge cannot be imposed at the next distribution and also cannot be made sooner than two years after the repurchase of the obligations. The advantage of a repurchase under these conditions lies in the fact that the concern is freed from all liens created by the Industrial Charges Law for two or three years and obtains a premium of fifteen per cent. of free assets in case of an increase of its capital employed in the business.

In order to give an opportunity to the industrial debtors to repurchase their individual obligations, the Trustee cannot sell their negotiable obligations until six months after they have been delivered to him and during this period the Trustee may accept any proposal for the immediate or gradual purchase of the individual obligations. After the passage of six months the Trustee is obliged before selling any of the individual obligations to inform the debtor and to allow an opportunity of repurchase during a period of one month. ${ }^{18}$ In any case of repurchase the purchase price must not exceed the principal amount of the obligations. Propositions may be made at any time for the repirchase of non-negotiable obligations. In the case of the repurchase of non-negotiable obligations a like principal amount of Industrial Bonds is to be destroyed by the Trustee.

Provisions are made for the division of the charge among various parcels of the real property of an enterprise, and, in some instances for the entire cancellation of the lien. In the

"Since the individual obligations must be delivered by February 28 , 1925, the Trustee, therefore, cannot sell the individial negotiable obligations until October I, I925. 
case of a sale of any land the property normally passes to the purchaser subject to the public law mortgage. In order, however, to permit sales of land on favorable terms, it is provided that, if several parcels of land are mortgaged, the Bank and the Trustee, upon application of the vendor must distribute the charge between the parcel of land sold and the remaining property, pro rata to the respective values. Property may be sold free of the charge if the value of the property sold does not exceed one-tenth of the total value of the concern's real property, provided that the aggregate of such sales shall not exceed 50,000 gold marks or one-half the value of the real property of the concern. There are other instances where, with the consent of the Trustee and the Bank, the extent of the lien may be restricted. The most important examples are the right of the debtor to demand that the lien be distributed over the various parcels of real estate in proportion to their value, or, if the value of the real property considerably exceeds the sum to which it is subject, to demand that the charge be limited to certain parcels; and, finally, the right of the debtor concerns to demand the total discharge of the lien of the mortgage upon the delivery of substituted security.

New York, N. Y.

Thomas K. Finletter. 